Abstracta Iranica Abstracta Iranica

Revue bibliographique pour le domaine irano-aryen

Volume 24 | 2003

Comptes rendus des publications de 2001

La naissance de la monnaie. Pratiques monétaires de l'Orient ancien. Paris, Presses Universitaires de France, 2001, 286 p., 8 pl.

Rémy Boucharlat

(2) OpenEdition

Journals

Édition électronique

URL : http://journals.openedition.org/abstractairanica/34309

DOI : $10.4000 /$ abstractairanica.34309

ISSN : 1961-960X

Éditeur :

CNRS (UMR 7528 Mondes iraniens et indiens), Éditions de l'IFRI

Édition imprimée

Date de publication : 15 mai 2003

ISSN : 0240-8910

Référence électronique

Rémy Boucharlat, "La naissance de la monnaie. Pratiques monétaires de l'Orient ancien. Paris, Presses Universitaires de France, 2001, 286 p., 8 pl. », Abstracta Iranica [En ligne], Volume 24 | 2003, document 67, mis en ligne le 05 janvier 2010, consulté le 25 septembre 2020. URL : http://

journals.openedition.org/abstractairanica/34309; DOI : https://doi.org/10.4000/abstractairanica 34309

Ce document a été généré automatiquement le 25 septembre 2020.

Tous droits réservés 


\title{
La naissance de la monnaie. Pratiques monétaires de l'Orient ancien. Paris, Presses Universitaires de France, 2001, 286 p., 8 pl.
}

\author{
Rémy Boucharlat
}

1 Un livre très attendu, par un des plus grands spécialistes de la numismatique antique orientale. On sait que la monnaie que nous connaissons encore est née en Asie Mineure au début du $6^{e}$ s. av.n.è., lorsque la puissance politique du moment était le royaume de Lydie, dirigé par Alyatte, le père de Crésus. Les rois perses adoptent cette forme de monnaie et la répandent (aux créséides, succèdent les dariques d'or et les sicles d'argent), mais ne l'imposent pas partout. En Mésopotamie et dans le Zagros les lingots d'argent en barres ou fragments (voir le trésor de Nush-i Jan), anonymes et non décorés, qui servaient de monnaie depuis plus de deux millénaires (et dont le poids fut repris par les premières monnaies) perdurent encore longtemps, ce qui explique la rareté des monnaies d'époque perse dans cette région comme en Iran.

2 Pourquoi alors cette invention et à ce moment, puisque le système antérieur fonctionnait bien? À cette question ancienne, G. Le Rider, rejetant les deux explications traditionnelles, l'une commerciale l'autre comptable, apporte sa propre hypothèse. Selon la première explication, la monnaie uniforme évite la vérification par la pesée; selon la seconde, la monnaie facilite les paiements. Pour l'A., les inconvénients du paiement par fragments de métal auraient dû alors stimuler la création de la monnaie dans les grands empires orientaux, bien avant le $6^{\mathrm{e}} \mathrm{s}$. Selon l'A., la raison serait d'ordre fiscal ; l'État fixe la valeur de la monnaie, au-dessus de la valeur réelle, pense-t-il, et la garantit ; il contrôle les émissions qui seules ont cours. Il obtient ainsi des rentrées de métal précieux apporté de l'extérieur comme de l'intérieur du pays et il réalise des profits. La notion de valeur nominale de la monnaie, celle que nous connaissons auj ourd'hui encore, apparaît donc à ce moment. 
3 L'introduction de la monnaie marque bien plus qu'un progrès économique, elle est aussi une manifestation forte du pouvoir politique, ce qu'ont compris les rois perses (qui ne thésaurisaient pas l'or et la monnaie, comme on l'écrit encore sur la foi de certains témoignages antiques erronés; ils le distribuaient et investissaient !).

Démarche lumineuse fondée sur un immense savoir, cet ouvrage est une magnifique synthèse destinée à durer. On n'y trouvera qu'un petit défaut qui pourrait être réparé : la faible quantité des illustrations et la qualité médiocre des reproductions.

INDEX

Thèmes : 3.2.2. Pré-Achéménides et Achéménides

\section{AUTEURS}

RÉMY BOUCHARLAT

CNRS - Lyon 